\title{
EVIDENCE-BASED NURSING INTERVENTIONS AND GUIDELINES FOR PRONE POSI- TIONING OF ADULT, VENTILATED PATIENTS: A SYSTEMATIC REVIEW
}

\author{
Suegnet Nortje \\ MCur \\ Senior Registered Nurse, Cardio-thoracic Intensive Care Unit

\section{Dr Elsabe Nel} \\ $\mathrm{PhD}$ \\ Senior Lecturer, Department of Nursing Science, University of Johannesburg \\ Corresponding author: ewnel@uj.ac.za
}

\section{Prof. Anna Nolte \\ $\mathrm{PhD}$ \\ Professor, Department of Nursing Science, University of Johannesburg}

Keywords: prone positioning; ventilated patients; intensive care; evidence-based; nursing guidelines

\begin{abstract}
Although the prone positioning of a critically ill patient poses a challenge to nursing interventions, it remains the responsibility of nurses to develop a way to provide the same basic and intensive care to those patients lying prone as to those lying supine. The purpose of this study was firstly to conduct a systematic review of the literature as exploration and description of the evidence in support of the beneficial nursing interventions during prone positioning of ventilated patients, and secondly to develop evidence-based nursing guidelines for the nursing process.
\end{abstract}

This exploratory, descriptive and retrospective systematic review includes data from 45 clinical trials, with a total population of 2148 patients. Data was extracted onto data abstraction forms, assessed for methodological quality and finally summarised in evidence tables. All statistical calculations for the meta-analysis were performed by the RevMan 4.2.8 program. Prone positioning showed significant $(p<0.0001)$ increases in the partial pressure of oxygen in arterial blood $\left(\mathrm{PaO}_{2}\right)$ weighted mean difference $(W M D=11.43)$ and the partial pressure of oxygen in arterial blood/fraction of inspired oxygen $\left(\mathrm{PaO}_{2} / \mathrm{FiO}_{2}\right)$ ratio $(W M D=21.58,95 \% \mathrm{Cl}=11.36 ; 31.8)$. The effects of complications, oxygenation and haemodynamic outcomes compared with the different prone-positioning protocols produced inconclusive results. Nursing guidelines for prone positioning were developed based on the best available evidence. The lack of related articles on nursing care of prone positioning was a drawback. Based on these results, recommendations are made towards further study on the nursing care of prone-positioned patients.

\section{OPSOMMING}

Hoewel maaglêposisionering van die pasiënt, wat in 'n kritieke toestand is, 'n uitdaging aan verpleegsorg bied, is dit steeds die verantwoordelikheid van die verpleegkundige om dieselfde basiese en kritieke sorg aan pasiënte te lewer in die maaglêposisie as aan pasiënte in die rugliggende posisie. Die doel van hierdie navorsing is eerstens om ' $n$ sistematiese ontleding van die literatuur te doen as verkennende en beskrywende bewyse van die voordelige verpleegintervensies gedurende maaglêposisionering van geventileerde pasiënte, en tweedens om navorsingsgebaseerde verpleegriglyne op te stel wat die verpleegproses betref.

Hierdie verkennende, beskrywende en retrospektiewe sistematiese ontleding sluit data in van 45 kliniese proewe met ' $n$ totale populasie van 2148 pasiënte. Data is deur middel van 'n gestandardiseerde data-ontledingsvorm verkry, vir die metodologiese kwaliteit daarvan geassesseer en in dataonttrekkingstabelle opgesom. Alle statistiese 
verwerkings vir die meta-analise is deur die RevMan 4.2.8-program gedoen. Maaglêposisionering het beduidende toenames $(p<0.0001)$ in die arteriële suurstofdruk $\left(\mathrm{PaO}_{2}\right)$ geweegde gemiddelde verskil $(\mathrm{GMV}=11.43)$ en die arteriële suurstofdruk/fraksie van geïnspireerde suurstof-verhouding $\left(\mathrm{PaO}_{2} / \mathrm{FiO}_{2}\right)(\mathrm{GMV}=21.58,95 \% \mathrm{Cl}=11.36$; 31.8) getoon. Die effek van die komplikasie-, oksigenerings-, en hemodinamiese uitkomste in vergelyking met die verskillende maaglêposisioneringsprotokolle het onbeduidende resultate gelewer. Verpleegriglyne vir maaglêposisionering is opgestel volgens die beste beskikbare navorsingsbewyse. Die tekort aan verpleegsorgverwante artikels oor maaglêposisionering word as ' $n$ leemte beskou. Op grond van hierdie resultate word aanbevelings gemaak vir verdere studies oor die verpleegsorg van maagliggende pasiënte.

\section{BACKGROUND}

Prone positioning improves oxygenation in patients with acute respiratory distress syndrome (ARDS) by shifting blood flow to the undamaged and better-ventilated regions of the lung (Gattinoni, Tognoni, Pesenti, Taccone, Mascheroni, Labarta, Malacrida, Giulio, Fumagalli, Pelosi, Brazzi \& Latini, 2001:568). ARDS is associated with high mortality rates. According to the ARDS Foundation (n.d.), the extrapolated incidence of ARDS in South Africa was 24512 out of an estimated population of 44448470 in 2004, Prone positioning challenges the normal day-to-day clinical practice of intensive care nurses. This procedure can be done with the help of a few experienced colleagues, but poses some risk to the patient. These risks include unplanned extubation, accidental removal of intravenous and arterial lines and underwater chest drain tubes, obstruction of invasive lines, pressure sores and joint contractures (McAuley, 2001:12).

Patients experience facial swelling, expel large amounts of oral and nasal secretions and may develop pressure sores on weight-bearing parts of the body (Balas, 2000:24). Unintended extubation, airway obstruction and difficulties coordinating the ventilator can result in critical events. To minimise these risks, it is important to prepare appropriately and anticipate potential complications. Most complications described in literature can be avoided by means of effective planning and nursing care of these patients.

According to Curley (1999:397), clinicians are currently attempting to design safe and effective guidelines for the use of prone positioning in critically ill patients with ARDS. Nurses should be able to assess, plan, implement and evaluate this procedure independently (Grossman \& Bautista, 2002:34). Curley (1999:397) suggests that evidence-based protocols and efficacy studies for nurses should be designed to determine the care requirements of these patients. The purpose of this research was firstly to conduct a systematic review in order to explore and describe the evidence in support of the beneficial nursing interventions during prone positioning of ventilated patients, and secondly to develop evidence-based nursing guidelines for the nursing process.

\section{METHOD}

The research design for this study can be described as an exploratory, descriptive and retrospective systematic review. Cook, Mulrow and Haynes (1997:376) describe a systematic review as a process that involves scientific strategies to synthesise the results of multiple primary studies that address a specific clinical question.

\section{Criteria for inclusion and exclusion of studies}

Berman and Parker (2002:11) promote inclusion and exclusion criteria in a meta-analysis to safeguard against selection bias. A systematic review was performed in this present study using experimental study designs (randomised controlled trials - RCTs) as well as comparative, non-randomised and observational studies as evidence. Selected studies included a population of adult or paediatric subjects that were ventilated and turned into the prone position. In addition, the search strategy was restricted to articles published or translated into English. According to Moher, Cook, Eastwood, Olkin, Rennie and Stroup (2000:1452), "[l]anguage-restricted meta-analyses [overestimate] the treatment effect by only $2 \%$ on average compared with language-inclusive meta-analyses". Studies that included neonates or animals were excluded. 


\section{Search strategy}

Evidence was gathered using bibliographical databases of systematic reviews and articles that might provide definitive primary research data. A well-formulated question guides the entire review process (Stamm, Lawrence \& Richardson, 1998:2). The question guiding this study was: Which nursing interventions during prone positioning will benefit the patient and reduce or eliminate complications? Glasziou, Irwig, Bain and Colditz (2001:17) suggest that a systematic approach be taken to break the study question down into components using a Venn diagram. The components nursing interventions, prone positioning and different outcomes - were searched. Studies were located using the following search strategies: The Cochrane Controlled Trials Register (CCTR), MEDLINE, ProQuest, EBSCOhost, CINAHL, the Internet, Citation Search and manual searching.

\section{Data collection}

The data collection process comprised the systematic extraction of relevant data onto standardised data abstraction forms. Hedin and Kallestal (2004:28) suggest that data abstraction forms be created in order to objectively note data from the original articles. A data abstraction form was adapted from the Handbook for compilation of reviews on interventions in the field of public health (Hedin \& Kallestal, 2004:28) to measure study characteristics and outcome measures. The data from this form was used in descriptive summaries and evidence tables. Data compiled in tables was then used for qualitative description and quantitative analysis (meta-analysis).

The evidence was grouped into the following categories: demographic data, ventilation strategies, prone protocols, responder and non-responder groups, mortality, prone complications, responder outcomes, overall oxygenation outcomes and haemodynamic outcomes. An additional table was created to group exclusions and contra-indications to prone positioning. According to Hammersley (2002:1), it is important that "the practical use of research [take] in the whole range of findings on a topic, not just the results from one or two studies. For this reason, reviews play a crucial role as a bridge between research and related areas of policymaking and practice". Systematic reviews are used to integrate existing information efficiently and provide data for rational decisionmaking (Mulrow, 1994:597).

Fifty-six articles were identified, 11 of which were excluded from this review, leaving a total of 45 articles used in the final review. Data was entered onto a spreadsheet and captured into the RevMan 4.2.8 software program. Evidence gained from RCTs was used for quantitative analysis, which included a comparison between the supine and the prone position. Outcomes were chosen based on the available outcomes measured in each randomised trial. A subgroup analysis was performed to compare the results to the different protocols of prone positioning and included the following: sub-group analysis by responders and non-responders; volume-controlled and pressure-controlled ventilation; prone position with support under the chest and pelvis or without support; time in prone position; number of turns from supine to prone position; the number of personnel involved in the process; and whether pronepositioned patients were both sedated and paralysed, or only sedated.

\section{Assessment of methodological quality}

A quality rating instrument was used to assess the methodological quality of each individual study, and was included with the data abstraction form. Each study was given a level of evidence in accordance with the Oxford Centre for Evidence-based Medicine levels of evidence and thereafter graded according to grades of recommendation (Phillips, Ball, Sackett, Badenoch, Straus, Haynes \& Dawes, 2001:1). This resulted in studies that rated $A$ to $D$, in which $A$ can be associated with studies of good quality and D with those of poor quality. The study quality of RCTs was evaluated in more detail by using The Jadad Quality Assessment Instrument for Clinical Trials (Jadad, Moore, Carroll, Jenkinson, Reynolds, Gavaghan \& McQuay, 1996:1). This instrument assesses randomisation, doubleblinding, withdrawals and dropouts according to a scoring system with a score from 0-5. RCTs with a Jadad score of more than or equal to 3 can be considered as a medium to good quality study. Studies with a Jadad score of less than 3 are considered to be poor in methodological quality, thereby reducing the validity of the systematic review. 


\section{Data analysis}

Data synthesis was achieved by a narrative summary of studies and, where appropriate, by statistically combining the data produced by individual studies (Briggs, 2001:4). All statistical calculations were performed by RevMan available from the Cochrane Collaboration (Review Manager, 2003). Meta-analysis for this systematic review involved the calculation of an estimate of the chance variation from the selected studies, namely the confidence interval $(\mathrm{Cl})$. Evidence gained from RCTs was presented in a graph which shows a point estimate of each study's effect size, with the $\mathrm{Cl}$ indicated by a horizontal line on either side of the point. This is also known as a forest plot (Hetherington, 2004:1). The treatment effect, effect size and the study size or variance were measured in each study.

An odds-ratio was used to compare dichotomous outcomes and the weighted mean difference (WMD) to measure continuous data. Statistical heterogeneity was tested using a chi-square statistic (to test whether the two variables were independent or related). The degrees of freedom were calculated to determine the significance of the value of the statistic (Burns \& Grove, 2001:571). Where the heterogeneity shows significance ( $P$-value $>0.1$ ), a random-effects model was used. Even though a significant chi-square value indicates difference, the magnitude of the difference is not revealed by the analysis (Burns \& Grove, 2001:572).

\section{RESULTS}

\section{Characteristics of studies}

Forty-five clinical trials involving prone positioning were identified, with a total population of 2148 patients. Fortytwo clinical trials had adult populations and three had paediatric populations (prone positioning protocols were found to be similar in both adult and paediatric populations). There were 13 RCTs, only seven of which could be included for quantitative analysis. Thirty-two non-randomised controlled trials consisted of crossover designs, retrospective analysis or chart reviews, clinical follow-up studies, prospective clinical cohort studies, case-series trials, physiological studies and descriptive and observational studies. The methodological quality assessment showed $18 \mathrm{~A}$-grade, $20 \mathrm{~B}$-grade and $3 \mathrm{C}$ - grade studies according to the grades of recommendation. Eight RCTs had a Jadad score below 3 , five had a Jadad score of 3 and no studies had a Jadad score above 3. Participants had a mean age of 49.7 years and a mean weight of $71 \mathrm{~kg}$. The percentage of patients with primary ARDS was $59 \%$, and $41 \%$ of patients in these studies presented with secondary ARDS.

\section{Outcomes}

All the haemodynamic parameters increased when the patient was turned from the supine to the prone position, but only pulmonary artery wedge pressure (PAWP) showed statistical significance. The following results were available from four studies with a total sample size of 60 subjects in each position. The test for overall effect, $p=0.0009$, represents a significantly higher PAWP in the prone position. PAWP was between 13.4 and $24.4 \mathrm{mmHg}$ in the prone position and between 10.5 and $22 \mathrm{mmHg}$ in the supine position (WMD $=2.94$ $\mathrm{mmHg}$ ). The normal value is $2-12 \mathrm{mmHg}$ (Beers \& Berkow, 1999:1625). These results correlate to those of a recent study performed by Ferguson, Meade, Hallett and Stewart (2002:1073). In their study the mean maximum PAWP reading among patients was 22.5 $\mathrm{mmHg}(95 \% \mathrm{Cl} 21.2-23.8)$ and the mean median PAWP was $16.6 \mathrm{mmHg}(95 \% \mathrm{Cl} 15.6-17.5)$.

Partial pressure of oxygen in arterial blood $\left(\mathrm{PaO}_{2}\right)$ and partial pressure of oxygen in arterial blood/fraction of inspired oxygen $\left(\mathrm{PaO}_{2} / \mathrm{FiO}_{2}\right)$ ratio (see figure 1 ) showed statistically significant improvements from the supine to the prone positions. These results were expected and in agreement with the outcomes of other trials on prone positioning. The $\mathrm{PaO}_{2} / \mathrm{FiO}_{2}$ ratio results are far below the normal range (80 to $100 \mathrm{mmHg}$ ), which confirms the diagnoses of ARDS (Thelan, Urden, Lough \& Stacy, 1998:662).

Nineteen trials classified their patients into responders (if they met certain oxygenation improvement criteria) and non-responders (if they did not meet these criteria). The patients were divided into a responder and nonresponder ratio, with $25 \%$ of patients classified as nonresponders and $75 \%$ as responders to prone positioning. 


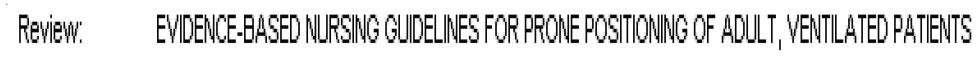

Comprisor: $\quad 02$ Prone versus supine (oxygendition)

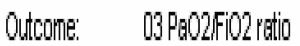

\begin{tabular}{|c|c|c|c|c|}
\hline $\begin{array}{l}\text { Study } \\
\text { or sth-coteyory }\end{array}$ & $\mathbb{N}$ & $\begin{array}{l}\text { Prone } \\
\text { Meer (SD) }\end{array}$ & $\mathbb{N}$ & $\begin{array}{l}\text { Supine } \\
\text { Meen (SD) }\end{array}$ \\
\hline Hexing 2002 & 12 & $269.00(68.00)$ & 12 & $194.00(66.00)$ \\
\hline Guepin 2004 & 317 & $210.00\{82.00\}$ & 338 & $193.00(76.00)$ \\
\hline Conley 2005 & 50 & $183.00(69.00\}$ & 49 & $176.00|62.00\rangle$ \\
\hline 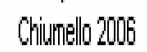 & 11 & $265.00(40.00\}$ & 11 & $206.20(38.70)$ \\
\hline
\end{tabular}

410

Total (95\% al)

390

imo (fivered)

$95 \%$

Weight

$\%$

WMO (fixed)

$95 \%$ C)



Test for overal effect. $Z=4.14$ ( $\mathrm{P}$ : 0.0001$)$

\section{$\begin{array}{lllll}.100 & -50 & 0 & 50 & 100\end{array}$ \\ Favours supine Favours prone}

Figure 1: Comparison of prone versus supine positioning with $\mathrm{PaO}_{2} / \mathrm{FiO}_{2}$ ratio as an outcome (RevMan 4.2.8)

Table 1: Complications that occurred in the prone position

\begin{tabular}{|l|l|}
\hline Complications & $\%$ \\
\hline & 28.0 \\
\hline Decrease in pulse oximetry $\left(\mathrm{SpO}_{2}\right)$ & 25.7 \\
\hline New pressure sores & 10.2 \\
\hline Bradycardia & 10.0 \\
\hline Cardiac arrest & 10.0 \\
\hline Decreased blood pressure & 6.3 \\
\hline Dislodged endotracheal tube & 5.7 \\
\hline Facial oedema & 3.5 \\
\hline Atelectasis & 3.2 \\
\hline Pneumothorax & 3.0 \\
\hline Blocked endotracheal tube & 0.8 \\
\hline Mild cutaneous and mucosal damage & 0.8 \\
\hline Intolerance to enteral feeding & 0.4 \\
\hline Loss of venous access & 0.1 \\
\hline SVT/tachycardia & 0.1 \\
\hline Contractures & 0.06 \\
\hline Corneal ulceration & 0.06 \\
\hline Loss of arterial access & \\
\hline
\end{tabular}


Prone positioning can also be combined with other treatment modalities. Among the clinical trials included, $14 \%$ of studies included inhaled nitric oxide therapy and $13 \%$ included extracorporeal membrane oxygenation (ECMO), airway pressure release ventilation (APRV) with unsupported spontaneous breathing, continuous rotation and sigh breaths. Prone positioning was mostly ( $73 \%$ of all studies) used effectively as the only treatment modality.

In 28 trials patients were both sedated and paralysed and in eight trials, patients were sedated only. The heart rate increased by a WMD of 3.06 beats/minute in sedated and paralysed patients. The heart rate increased (insignificantly) more with sedation and paralysis than with sedation only. This may be due to the type of muscle relaxant used. Many of the studies included mentioned the use of Pancuronium bromide, a non-depolarising curaremimetic muscle relaxant which acts as an acetylcholine antagonist on neuromuscular junctions. A side effect of this drug is that it raises heart rate moderately (Wikipedia, n.d. Pancuronium). $\mathrm{PaO}_{2}$ increased significantly in patients who were sedated and paralysed.

Complications that occurred with prone positioning were found throughout the literature. These are listed in Table 1 from the most common complication to the least. Pressure sores were found on the face, thorax and anterior chest wall, shoulders, iliac crest, knees, lips, tongue, forehead, hips, chin, genitalia, upper chest wall (necrosis) and ears.

It was noted that endotracheal tube dislodgement and the loss of arterial or venous access occurred more often in patients in the supine than with those in the prone position. Most patients in the clinical trials included represented with mild cutaneous damage or facial oedema to some degree. Unfortunately these complications were not measured or recorded in numerical values. There was not enough data to compare the prone protocols with complications related to prone positioning.

The total number of ventilated days was found to be insignificantly more in the supine than in the prone position. Furthermore, the patients' length of stay in the intensive care unit (ICU) was insignificantly longer (16.5 to 26.6 days) in the prone position than in the supine position (19.4 to 24.5 days). The mortality for patients in the clinical trials included was $33.5 \%$.

\section{EVIDENCE-BASED NURSING GUIDELINES}

Clinical guidelines have been defined as "systematically developed statements to assist both practitioner and patient decisions in specific circumstances" (Eccles \& Mason, 2001:1). The following guidelines have been compiled by the researcher from the results and evidence obtained through summarising all available data and quantitative analysis. Nursing guidelines according to the nursing process are presented in Table 2 as actions, supported by evidence.

\section{DISCUSSION}

Prone positioning shows significant increases in the oxygenation outcomes of patients with ARDS or acute lung injury. Complications with this procedure may be numerous, but these did not occur to the extent that was expected. Nursing interventions that benefited the patient and reduced complications (according to the best available evidence) are described in Table 2 .

This study has several limitations. The specific objective of this study was to obtain evidence representative of the nursing activities related to prone positioning. Nursing-care related articles were few and selected articles presented different treatment strategies and outcomes, which mostly did not include nursing activities. A further limitation of this review is the number of studies of poor methodological quality. Most of the studies that were included in this review were of a short duration and thus no long-term benefits or complications of the prone position could be assessed.

\section{CONCLUSION}

Comparisons were made between the supine and the prone positions. Different outcomes were measured, which included oxygenation outcomes, responder and non-responder groups, haemodynamic outcomes, complications in the prone position, mortality, the length of stay in ICU and the total number of ventilated days. These outcomes were measured against the existing prone protocols in order to provide an answer to the research question. The results that were analysed 
Table 2: Evidence-based nursing guidelines according to the nursing process (regarding assessment, planning, implementation and evaluation)

\begin{tabular}{|c|c|}
\hline \multicolumn{2}{|l|}{ ASSESSMENT } \\
\hline ACTION & EVIDENCE \\
\hline $\begin{array}{l}\text { Assess the patient's indications and } \\
\text { contra-indications to prone positioning. }\end{array}$ & $\begin{array}{l}\text { There is a significant improvement in the } \mathrm{PaO}_{2} / \mathrm{FiO}_{2} \text { ratio with } \\
\text { patients in the prone position. Prone positioning has been } \\
\text { indicated in the acute respiratory distress syndrome (ARDS) } \\
\text { with } \mathrm{PaO}_{2} / \mathrm{FiO}_{2}<200 \mathrm{mmHg} \text {. In } 45 \text { clinical trials patients with } \\
\text { the following conditions were not turned to the prone position: } \\
\text { diseases that relate to severe cardiac failure, acute myocardial } \\
\text { infarction, cerebral oedema, decreased cerebral perfusion } \\
\text { pressure, increased intracranial pressure, haemodynamic } \\
\text { instability, spinal instability and fractures, chronic obstructed } \\
\text { pulmonary disease, abdominal surgery, open abdomen } \\
\text { (peritonitis) and ascitis, cranial trauma and craniofacial surgery, } \\
\text { unstable long bone fractures, flail chest or chest wall } \\
\text { abnormalities, some infective pulmonary conditions, } \\
\text { orthopaedic traction, recent sternotomy, acute bleeding, } \\
\text { haemoptysis and alveolar haemorrhage, extensive skin lesions, } \\
\text { bone marrow transplants, lung transplants, liver transplants and } \\
\text { pregnancy. }\end{array}$ \\
\hline $\begin{array}{l}\text { Assess the patient's need for sedation or } \\
\text { paralysis. }\end{array}$ & $\begin{array}{l}\text { Sedation together with paralysis of the patient was more often } \\
\text { used as part of the prone protocols than sedation only ( } 28 \text { vs } 8 \\
\text { trials). Intracranial pressure (ICP) increased with a WMD of } \\
10.2 \text { and central venous pressure (CVP) increased by } 0.55 \\
\mathrm{mmHg} \text { in patients who were only sedated. Heart rate increased } \\
\text { by a WMD of } 3.06 \text { beats minute in sedated and paralysed } \\
\text { patients. } \mathrm{PaCO}_{2} \text { decreased with a WMD of }-0.61 \text { in patients } \\
\text { who were only sedated. } \mathrm{PaO}_{2} \text { increased significantly in patients } \\
\text { who were both sedated and paralysed. }\end{array}$ \\
\hline $\begin{array}{l}\text { Assess the patient's nutritional needs } \\
\text { and determine by which feeding method } \\
\text { the patient would benefit. }\end{array}$ & $\begin{array}{l}\text { Only } 14 \text { of } 1626 \text { patients showed intolerance to enteral feeding. } \\
\text { Both parenteral and enteral feeding were used in prone } \\
\text { protocols. Only nine studies on prone positioning mention } \\
\text { nutrition and feeding. Enteral feeding was given continuously in } \\
\text { five studies. }\end{array}$ \\
\hline $\begin{array}{l}\text { Assess each individual patient's need } \\
\text { for airway clearance (suctioning). }\end{array}$ & $\begin{array}{l}\text { The endotracheal tube was blocked in } 3 \% \text { of patients. In-line } \\
\text { suctioning catheters can be placed to ensure easier access to } \\
\text { clear the airway of secretions. }\end{array}$ \\
\hline $\begin{array}{l}\text { Assess each patient for skin condition } \\
\text { and integrity before and after prone } \\
\text { positioning. }\end{array}$ & $\begin{array}{l}\text { A total of } 25.7 \% \text { of the patients developed new pressure sores } \\
\text { during prone positioning. }\end{array}$ \\
\hline Assess the stability of the patient's & Patients may become more unstable with the turning procedure \\
\hline
\end{tabular}




\begin{tabular}{|c|c|}
\hline $\begin{array}{l}\text { condition using haemodynamic } \\
\text { parameters and oxygenation outcomes. }\end{array}$ & $\begin{array}{l}\text { from supine to prone position. This can be confirmed by the } \\
\text { complications that were found in this review. A decrease in } \\
\text { pulse oximetry }\left(\mathrm{SpO}_{2}\right) \text { represented } 28 \% \text { of patients. } \\
\text { Tachycardia or supra-ventricular tachycardia occurred in } 0.1 \% \\
\text { of patients. In one study } 175 \text { patients had cardiac arrest }(10 \%) \text {, } \\
\text { bradycardia represented } 10.2 \% \text { of the population and } 283 \\
\text { patients out of } 791 \text { had decreased blood pressure (10\%). }\end{array}$ \\
\hline \multicolumn{2}{|l|}{ PLANNING } \\
\hline ACTION & EVIDENCE \\
\hline $\begin{array}{l}\text { Plan a safe environment (e.g. } \\
\text { emergency trolley within reach) to } \\
\text { ensure fast action in case of life- } \\
\text { threatening events. }\end{array}$ & $\begin{array}{l}\text { Complications that occur in prone positioning can have life- } \\
\text { threatening consequences that require immediate action. The } \\
\text { evidence shows that the endotracheal tube was dislodged in } \\
6.3 \% \text { of patients, which would require immediate re-intubation. } \\
\text { Loss of venous access occurred in seven patients, and loss of } \\
\text { arterial access in one patient. These patients are mostly } \\
\text { dependent on inotropic support through invasive lines, which, } \\
\text { when accidentally removed, can cause a critical event. }\end{array}$ \\
\hline $\begin{array}{l}\text { Plan for five people (ensure that } \\
\text { someone who can intubate is near or } \\
\text { within reach) to assist in the prone- } \\
\text { positioning process. }\end{array}$ & $\begin{array}{l}\text { The evidence shows that the endotracheal tube was dislodged } \\
\text { in } 6.3 \% \text { of patients, which would require immediate re- } \\
\text { intubation. The evidence suggests that three to six people } \\
\text { should be involved in the turning process. According to the } \\
\text { results, the ideal number of personnel would be } 4.6 \text { (rounded } \\
\text { off to 5) people. Heart rate increased and the mean arterial } \\
\text { pressure (MAP) decreased if only three people assisted in the } \\
\text { turning process. }\end{array}$ \\
\hline $\begin{array}{l}\text { Plan in advance for specialised beds, } \\
\text { mattresses or turning equipment, e.g. } \\
\text { air-cushioned beds or Vollman prone } \\
\text { positioner. }\end{array}$ & $\begin{array}{l}\text { Additional turning and positioning equipment or a pressure- } \\
\text { relieving aid was used in } 15 \text { studies. In } 9 \text { of } 15 \text { studies, patients } \\
\text { were placed on air-cushioned beds, which have special air } \\
\text { mattresses with a dynamic cell design and automatic } \\
\text { adjustment for patient weight (Gainnier, Michelet, Thirion, Arnal, } \\
\text { Sainty \& Papazian, 2003:2720). }\end{array}$ \\
\hline $\begin{array}{l}\text { Plan the length of time for which the } \\
\text { patient will be in the prone position } \\
\text { according to the physician's prescription } \\
\text { and the patient's tolerance of the } \\
\text { position. }\end{array}$ & $\begin{array}{l}\text { The minimum duration in the prone position was } 6.4 \text { hours and } \\
\text { the maximum duration was } 20.7 \text { hours. Oxygenation outcomes } \\
\text { were positive for patients who remained in the prone position } \\
\text { for less than } 12 \text { hours. These results were not significant. } \\
\text { Haemodynamic outcomes varied in their results. Heart rate and } \\
\text { MAP increased with the patient in the prone position for less } \\
\text { than } 12 \text { hours, while the mPAP (mean pulmonary artery } \\
\text { pressure) lowered during this time, which can be considered a } \\
\text { positive response. New pressure sores developed more in }\end{array}$ \\
\hline
\end{tabular}




\begin{tabular}{|c|c|}
\hline & $\begin{array}{l}\text { patients who were in the prone position for more than } 12 \text { hours. } \\
\text { Mortality was less in patients who remained in the prone } \\
\text { position for a shorter period. From this evidence, more } \\
\text { favourable results were obtained in patients who remained in } \\
\text { the prone position for a period less than } 12 \text { hours. }\end{array}$ \\
\hline \multicolumn{2}{|l|}{ IMPLEMENTATION } \\
\hline ACTION & EVIDENCE \\
\hline $\begin{array}{l}\text { Organise the five staff members as } \\
\text { follows: one at the patient's head and } \\
\text { two on either side of the patient's body. }\end{array}$ & $\begin{array}{l}\text { The person at the patient's head should be responsible for } \\
\text { tracheal intubation. Someone else should be responsible for the } \\
\text { patency of the central lines (Chatte, Sab, Dubois, Sirodot, } \\
\text { Gaussorgues \& Robert, 1997:474). }\end{array}$ \\
\hline $\begin{array}{l}\text { Choose an appropriate mode of } \\
\text { ventilation and individualise ventilator } \\
\text { settings. }\end{array}$ & $\begin{array}{l}\text { Volume-controlled mode of ventilation was used in } 14 \text { prone } \\
\text { protocols and the pressure-controlled mode of ventilation was } \\
\text { used in } 9 \text { trials. The } \mathrm{PaO}_{2}, \mathrm{PaO}_{2} / \mathrm{FiO}_{2} \text { ratio and minute volume } \\
\text { showed better results in the volume-controlled mode of } \\
\text { ventilation. These results were not conclusive, however, owing } \\
\text { to the lack of data on the pressure-controlled mode of } \\
\text { ventilation. Throughout study protocols, the mean } \mathrm{FiO}_{2} \text { (fraction } \\
\text { of inspired oxygen) was } 0.8 \% \text {, the mean frequency setting was } \\
18.4 \text {, tidal volume (measured as } \mathrm{ml} / \mathrm{kg} \text { ) was } 8.6 \mathrm{ml} / \mathrm{kg} \text {, and the } \\
\text { maximum PEEP (Positive end expiratory pressure) applied was } \\
11.1 \mathrm{mmHg} \text {. }\end{array}$ \\
\hline $\begin{array}{l}\text { Monitor the patient's oxygenation } \\
\text { outcomes by performing blood gas } \\
\text { sampling before and after prone } \\
\text { positioning and regularly on an } \\
\text { individual basis. }\end{array}$ & $\begin{array}{l}28 \% \text { of patients presented with a decrease in } \mathrm{SpO}_{2} \text { and } 25 \% \text { of } \\
\text { patients can be classified as non-responders. } 75 \% \text { of patients } \\
\text { responded positively to prone positioning with significant } \\
\text { increases in } \mathrm{PaO}_{2} \text {. Blood gas sampling was regularly performed } \\
\text { in all studies to measure the outcome and effect of treatment. } \\
\text { The effects and outcomes of prone positioning should also be } \\
\text { assessed when this treatment is used. }\end{array}$ \\
\hline $\begin{array}{l}\text { Aspirate gastric content before prone } \\
\text { positioning and continue with } \\
\text { appropriate nutrition after the procedure. }\end{array}$ & $\begin{array}{l}\text { Only two studies mentioned that gastric content was aspirated } \\
\text { (and in both cases it was done to measure residual volumes). }\end{array}$ \\
\hline $\begin{array}{l}\text { Secure the patient's endotracheal tube } \\
\text { before prone positioning. In-line } \\
\text { suctioning catheters can be placed to } \\
\text { ensure easier access to clear the airway } \\
\text { of secretions and suction when } \\
\text { necessary. }\end{array}$ & $\begin{array}{l}\text { Only a few studies mentioned suctioning practices (clearing of } \\
\text { the airway), with no mention of the frequency and actual } \\
\text { suctioning methods. Suctioning was mostly performed before } \\
\text { and after positioning (Blanch, Mancebo, Perez, Martinez, Mas, } \\
\text { Betbese, Joseph, Ballús, Lucangelo \& Bak 1997:1034; Chatte } \\
\text { et al. 1997:474; Johannigman, Davis, Miller, Campbell, } \\
\text { Luchette, Frame \& Branson, 2001:590). Closed suctioning } \\
\text { systems were used (Fridrich, Krafft, Hochleuthner \& Mauritz, }\end{array}$ \\
\hline
\end{tabular}




\begin{tabular}{|c|c|}
\hline & 1999:1207). \\
\hline $\begin{array}{l}\text { Disconnect monitoring devices or lines } \\
\text { that could obstruct or restrict the turning } \\
\text { of a patient. Ensure the patient's safety } \\
\text { at all times or rearrange monitoring } \\
\text { cables, probes and invasive monitoring } \\
\text { devices before the procedure to ensure } \\
\text { continuous monitoring. }\end{array}$ & $\begin{array}{l}\text { Vital signs were monitored closely before and after turning } \\
\text { events in most studies, for example in the study by Goettler, } \\
\text { Pryor, Hoey, Phillips, Balas and Shapiro (2002:453). Evidence } \\
\text { from the trials included suggests that the patient should be } \\
\text { removed from certain monitoring devices to facilitate an } \\
\text { unrestricted turn (Mentzelopoulos, Zakynthinos, Roussos, } \\
\text { Tzoufi \& Michalopoulos, 2003:1760). }\end{array}$ \\
\hline $\begin{array}{l}\text { Monitor haemodynamic parameters } \\
\text { before, during and after the prone } \\
\text { positioning process for early detection of } \\
\text { any instability. }\end{array}$ & $\begin{array}{l}\text { All the haemodynamic parameters increased when the patient } \\
\text { was turned from the supine to the prone position. Pulmonary } \\
\text { artery wedge pressure increased significantly. In order to } \\
\text { monitor patients effectively, these patients had indwelling } \\
\text { catheters (pulmonary artery, arterial and venous), pulse } \\
\text { oximetry probes, electrocardiographic leads, Foley catheters } \\
\text { and a few other devices (e.g. cardiac output monitors). In all } 45 \\
\text { trials included, these devices were used to some extent to } \\
\text { facilitate continuous measurements and monitoring. }\end{array}$ \\
\hline \multicolumn{2}{|c|}{ Turning the patient into the prone position and care provided in this position } \\
\hline $\begin{array}{l}\text { Option 1: Position the patient's head } \\
\text { laterally, or } \\
\text { Option 2: Position the patient's head } \\
\text { facing downward (on forehead and } \\
\text { chin). } \\
\text { Provide pressure relief under pressure } \\
\text { parts, e.g. the patient's ears, forehead or } \\
\text { chin, and to avoid eye injuries. }\end{array}$ & $\begin{array}{l}\text { Eleven studies supported a lateral position (the patient's head } \\
\text { was turned laterally, supported under the side of the head). } \\
\text { Theoretically the lateral positioning of a patient's head may } \\
\text { compress the jugular veins, which can cause raised intracranial } \\
\text { pressure. Seven studies supported a full frontal position (head } \\
\text { in total prone position and supported under the forehead and } \\
\text { chin). In the study by Jolliet, Bulpa and Chevrolet (1998:1980), } \\
\text { three patients developed pressure sores on the chin. The } \\
\text { evidence found one patient with an infectious corneal } \\
\text { ulceration. There was no evidence suggesting that one position } \\
\text { was preferred over the other. }\end{array}$ \\
\hline $\begin{array}{l}\text { Ensure the patency and correct position } \\
\text { of invasive lines and tubes. }\end{array}$ & $\begin{array}{l}\text { The loss of venous access occurred in seven patients and the } \\
\text { loss of arterial access in one patient. }\end{array}$ \\
\hline $\begin{array}{l}\text { Apply a moisture barrier to the patient's } \\
\text { entire face to protect the skin integrity } \\
\text { against secretions from the nose and } \\
\text { mouth. }\end{array}$ & $\begin{array}{l}\text { Most patients presented with mild cutaneous damage or facial } \\
\text { oedema to some degree. Unfortunately these complications } \\
\text { were not measured or recorded in numerical values. Care } \\
\text { should be taken to avoid these complications. }\end{array}$ \\
\hline $\begin{array}{l}\text { Option 3: Turn the patient without any } \\
\text { support under the chest or pelvis (the } \\
\text { patient lies flat against the mattress), or } \\
\text { Option 4: Support the patient's body } \\
\text { under the chest and pelvis (with pillows }\end{array}$ & $\begin{array}{l}\text { Nine studies supported option } 3 \text { and } 13 \text { studies option } 4 . \\
\text { Oxygenation improved markedly with option } 3 \text {. In the group } \\
\text { without support under the chest and pelvis (option } 3) \text {, the } \\
\mathrm{PaO}_{2} / \mathrm{FiO}_{2} \text { ratio showed a significant increase with a WMD of } \\
61.02(95 \% \mathrm{Cl} 32.67 ; 89.38) \text { between the supine and prone }\end{array}$ \\
\hline
\end{tabular}


or other pressure-relieving materials) positions.

with the patient's abdomen protruding

and hanging free from the bed.

Option 5: Keep the patient's arms straight and parallel to the body, or

Option 6: Bend one arm at the shoulder and $90^{\circ}$ at the elbow.

Provide movement to extremities on a regular basis and turn the patient's head and arms two hourly to the opposite position.

In 12 studies the patients' arms were placed next to their bodies (parallel) and in four studies the patients' arms were bent at the shoulder and at $90^{\circ}$ at the elbow.

Position the patient's body into left and right lateral decubitus position for nursing care, or turn the patient back to the supine position.

Head and arm positions were changed two hourly in studies that reported mobilisation of extremities, for example in the study by Offner, Haenel, Moore, Biffl, Franciose and Burch (2000:225). Three patients presented with contractures.

According to the evidence, 4.4 hours were used in the supine position for procedures and nursing care. In the study by Guerin, Gaillard, Lemasson, Ayzac, Girard, Beuret, Palmier, Viet Le, Sirodot, Rosselli, Cadiergue, Sainty, Barbe, Combourieu, Debatty, Rouffineau, Ezingeard, Millet, Guelon, Rodriguez, Martin, Renault, Sibille and Kaidomar (2004:2381), it was suggested that patients be turned to a left and right lateral decubitus position.

Record the patient's response or nonresponse to this procedure. It is suggested that patients be monitored meticulously for the first 30 minutes to an hour to assess their response to the procedure.

In 45 studies $25 \%$ were non-responders and $75 \%$ were responders to prone positioning. Patients who first responded generally maintained or increased their oxygenation response. Patients who did not respond initially may respond at a second or third attempt. A patient was considered a responder when the $\mathrm{PaO}_{2} / \mathrm{FiO}_{2}$ ratio increased by at least 15 to $20 \%$ or more, or when there was an improvement in $\mathrm{PaO}_{2}$ of more than 7 to 10 $\mathrm{mmHg}$ or $20 \%$ after 30 minutes. There were a few variations on these classification criteria which included an increase of 20 $\mathrm{mmHg}$ in the $\mathrm{PaO}_{2} / \mathrm{FiO}_{2}$ ratio or a decrease of more than $10 \%$ in the oxygenation index.

Monitor the patient's intake and urine output.

In the study by Chiumello, Cressoni, Racagni, Landi, Bassi, Polli, Carlesso and Gattinoni (2006:6), urine output was less in the prone (mean $90 ; \pm S D 64$ ) than in the supine (mean 111; 土SD 71) position.

\begin{tabular}{|l|l|}
\hline EVALUATION \\
\hline ACTION & EVIDENCE \\
\hline $\begin{array}{l}\text { Evaluate the patient's oxygenation } \\
\text { response to the prone position and } \\
\text { follow up on non-responders. }\end{array}$ & $\begin{array}{l}\text { The overall shunt fraction in patients decreased from } 34.3 \% \text { in } \\
\text { the supine to } 26.6 \% \text { in the prone position. } \mathrm{PaO}_{2} \text { increased from } \\
89.3 \mathrm{mmHg} \text { in the supine to } 137.2 \mathrm{mmHg} \text { in the prone position. }\end{array}$ \\
\hline Evaluate the occurrence of & Mild cutaneous and mucosal damage occurred in 14 patients \\
\hline
\end{tabular}




\begin{tabular}{|c|c|}
\hline $\begin{array}{l}\text { complications and take appropriate } \\
\text { nursing actions to prevent these } \\
\text { complications. }\end{array}$ & and facial oedema in 93 cases. \\
\hline $\begin{array}{l}\text { Evaluate the patient's condition and } \\
\text { determine whether one turn is sufficient } \\
\text { or whether more turns should be } \\
\text { performed. }\end{array}$ & $\begin{array}{l}\text { The mean number of prone cycles was } 10.6 \text { times, ranging from } \\
1-23 \text { times. Oxygenation outcomes improved in patients who } \\
\text { were turned only once. The dislodgement of endotracheal tubes } \\
\text { and the number of new pressure sores occurred more often in } \\
\text { patients with two or more turning events. }\end{array}$ \\
\hline
\end{tabular}

presented the best available evidence to support nursing guidelines for prone positioning of adult, ventilated patients.

The studies that were included in this review reflect mostly medical treatment and the outcomes based on this treatment. The researcher would recommend further research (nursing research) that addresses nursing actions and outcomes regarding patients in the prone position.

\section{REFERENCES}

ACUTE RESPIRATORY DISTRESS SYNDROME FOUNDATION (n.d.). Available from: http://www.ardsusa.org/ (Accessed 9 October 2006).

ARDS See ACUTE RESPIRATORY DISTRESS SYNDROME.

BALAS, MC 2000: Prone positioning of patients with acute respiratory distress syndrome: Applying research to practice. Critical Care Nurse, 20(1):24-37.

BEERS, MH \& BERKOW, R eds. 1999: The Merck manual of diagnosis and therapy. Whitehouse Station: Merck Research Laboratories.

BERMAN, NG \& PARKER, RA 2002: Meta-analysis: Neither quick nor easy. BMC Medical Research Methodology, 2(1):10. Available from: http://www.biomedcentral.com/1471-2288/2/10 (Accessed 7 March 2005).

BLANCH, L; MANCEBO, J; PEREZ, M; MARTINEZ, M; MAS, A; BETBESE, AJ; JOSEPH, D; BALLÚS, J; LUCANGELO, U \& BAK, E 1997: Short-term effects of prone position in critically ill patients with acute respiratory distress syndrome. Intensive Care Medicine, 23(10):1033-1039.

BRIGGS, J 2001: Changing practice, evidence based practice information sheets for health professionals; An introduction to systematic reviews, supplement 1 . The Joanna Briggs Institute for Evidence Based Nursing and Midwifery. Available from: http:/ /www.joannabriggs.edu.au (Accessed 11 August 2005).
BURNS, N \& GROVE, SK 2001: The practice of nursing research: Conduct, critique, $\&$ utilization; $4^{\text {th }}$ edition. Philadelphia: WB Saunders.

CHATTE, G; SAB, J; DUBOIS, J; SIRODOT, M; GAUSSORGUES, P \& ROBERT, D 1997: Prone position in mechanically ventilated patients with severe acute respiratory failure. American Journal of Respiratory Critical Care Medicine, 155(2):473-478. CHIUMELLO, D; CRESSONI, M; RACAGNI, M; LANDI, L; BASSI, GL; POLLI, F; CARLESSO, E \& GATTINONI, L 2006: Effects of thoracopelvic supports during prone position in patients with acute lung injury/acute respiratory distress syndrome: A physiological study. Critical Care, 10(3):R87.

COOK, DJ; MULROW, CD \& HAYNES, B 1997: Systematic reviews: Synthesis of best evidence for clinical decisions. Annals of Internal Medicine, 126(5):376-380.

CURLEY, MAQ 1999: Prone positioning of patients with acute respiratory distress syndrome: A systematic review. American Journal of Critical Care, 8(6):397-406.

ECCLES, M \& MASON, J 2001: How to develop cost-conscious guidelines. Health Technology Assessment, 5(16):1-69.

FERGUSON, ND; MEADE, MO; HALLETT, DC \& STEWART, TE 2002: High values of the pulmonary artery wedge pressure in patients with acute lung injury and acute respiratory distress syndrome. Intensive Care Medicine, 28(8):1073-1077.

FRIDRICH, P; KRAFFT, P; HOCHLEUTHNER, H \& MAURITZ, W 1999: The effects of long-term prone positioning in patients with traumainduced adult respiratory distress syndrome. Anaesthesia Analgesia, 83(6):1206-1211.

GAINNIER, M; MICHELET, P; THIRION, X; ARNAL, J-M; SAINTY, J-M \& PAPAZIAN, L 2003: Prone position and positive end-expiratory pressure in acute respiratory distress syndrome. Critical Care Medicine, 31(12):2719-2726.

GATTINONI, L; TOGNONI, G; PESENTI, A; TACCONE, P; MASCHERONI, D; LABARTA, V; MALACRIDA, R; GIULIO, P; FUMAGALLI, R; PELOSI, P; BRAZZI, L \& LATINI, R 2001: Effect of prone positioning on the survival of patients with acute respiratory failure. The New England Journal of Medicine, 235(8):568- 
574.

GLASZIOU, P; IRWIG, L; BAIN, C \& COLDITZ, G 2001: Systematic reviews in health care. A practical guide. Cambridge: University Press.

GOETTLER, CE; PRYOR, JP; HOEY, BA; PHILLIPS, JK; BALAS, MC \& SHAPIRO, MB 2002: Prone positioning does not affect cannula function during extracorporeal membrane oxygenation or continuous renal replacement therapy. Critical Care, 6(5):452455.

GROSSMAN, S \& BAUTISTA, C 2002: Collaboration yields costeffective, evidence-based nursing protocols. Orthopedic Nursing, 21(3):30-37.

GUERIN, C; GAILLARD, S; LEMASSON, S; AYZAC, L; GIRARD, R; BEURET, P; PALMIER, B; VIET LE, Q; SIRODOT, M; ROSSELLI, S; CADIERGUE, V; SAINTY, J-M; BARBE, P; COMBOURIEU, E; DEBATTY, D; ROUFFINEAU, J; EZINGEARD, E; MILLET, O; GUELON, D; RODRIGUEZ, L; MARTIN, O; RENAULT, A; SIBILLE, J-P \& KAIDOMAR, M 2004: Effects of systematic prone positioning in hypoxemic acute respiratory failure: A randomized controlled trial. Journal of the American Medical Association, 292(19):23792387.

HAMMERSLEY, M 2002: Systematic or unsystematic, is that the question? Some reflections on the science, art, and politics of reviewing research evidence. Presentation Public Health Evidence Steering Group of the Health Development Agency. Available from: h t t p : / / w w w. h d a. n h s. uk/e vide n c e / sys_unsys_phesq_hammersley.pdf (Accessed 6 April 2006). HEDIN, A \& KALLESTAL, C 2004: Knowledge-based public health work. Part 2. Handbook for compilation of reviews on interventions in the field of public health. National Institute of Public Health. Available from: http://www.fhi.se (Accessed 6 April 2005).

HETHERINGTON, J 2004: Newcomers' guide. The Cochrane ColIaboration. Available from: file://E:ICochrane Collaboration newcomers'guide.htm (Accessed 17 June 2005).

JADAD, AR; MOORE, RA; CARROLL, D; JENKINSON, C; REYNOLDS, DJ; GAVAGHAN, DJ \& MCQUAY, HJ 1996: Assessing the quality of reports of randomized clinical trials: Is blinding necessary? Controlled Clinical Trials, 17(1):1-12.

JOHANNIGMAN, JA; DAVIS, K; MILLER, SL; CAMPBELL, RS; LUCHETTE, FA; FRAME, SB \& BRANSON, RD 2001: Prone positioning and inhaled nitric oxide: Synergistic therapies for acute respiratory distress syndrome. The Journal of Trauma: Injury, Infection, and Critical Care, 50(4):589-596.

JOLLIET, P; BULPA, P \& CHEVROLET, J 1998: Effects of the prone position on gas exchange and hemodynamics in severe acute respiratory distress syndrome. Critical Care Medicine, 26(12):1977-1985.

MCAULEY, DF 2001: Guidelines for the use of prone ventilation in acute respiratory distress syndrome and acute lung injury. A dissertation submitted for the intercollegiate Board Diploma in Intensive Care Medicine, Belfast.

MENTZELOPOULOS, SD; ZAKYNTHINOS, SG; ROUSSOS, C; TZOUFI, MJ \& MICHALOPOULOS, AS 2003: Prone position improves lung mechanical behaviour and enhances gas exchange efficiency in mechanically ventilated chronic obstructive pulmonary disease patients. Anaesthetic Analgesic, 96(6):1756-1767.

MOHER, D; COOK, DJ; EASTWOOD, SL; OLKIN, I; RENNIE, D \& STROUP, DF 2000: Improving the quality of reports of meta-analyses of randomised controlled trials: The QUOROM statement. British Journal of Surgery, 87(11):1448-1454. Available from: http:/ /www.bjs.co.uk (Accessed 5 October 2004).

MULROW, CD 1994: Systematic reviews: Rationale for systematic reviews. Education and debate. British Medical Journal, 309(6954):597-599.

OFFNER, PJ; HAENEL, JB; MOORE, EE; BIFFL, WL; FRANCIOSE, RJ \& BURCH, JM 2000: Complications of prone ventilation in patients with multisystem trauma with fulminant acute respiratory distress syndrome. Journal of Trauma: Injury, Infection and Critical Care, 48(2):224-228.

PHILLIPS, B; BALL, C; SACKETT, D; BADENOCH, D; STRAUS, S; HAYNES, B \& DAWES, M 2001: Levels of evidence and grades of recommendation. Oxford Centre for Evidence-based Medicine. Available from: http://www.cebm.net (Accessed 7 December 2005).

REVIEW MANAGER (RevMan) 2003: Version 4.2.8 for Windows. Copenhagen: The Nordic Cochrane Centre, The Cochrane Collaboration.

STAMM, K; LAWRENCE, V \& RICHARDSON, S 1998: Getting started in systematic reviews. Semi-annual newsletter. VA Center of Excellence. San Antonio and Charleston. Available from: http:// www.sanantonio-asa.uthscsa.edu/pub/downloads/ verdict_98fall.pdf (Accessed 6 April 2006).

THELAN, LA; URDEN, LD; LOUGH, ME \& STACY, KM 1998: Critical care nursing; diagnosis and management; $3^{\text {rd }}$ edition. St. Louis: Mosby.

WIKIPEDIA (n.d.) Acute respiratory distress syndrome. Available from : h t t p : / / w w w. en.wikipedia.org/wiki/ Acute_respiratory_distress_syndrome (Accessed 10 October 2006).

WIKIPEDIA (n.d.) Pancuronium. Available from: (http:// en.wikipedia.org/wiki/Pancuronium) (Accessed 10 October 2006) 